日本オリエント学会だより

「西アジア文化の東漸と仏教美術」

東京国立博物館学芸部東洋考古室長 杉山 二郎

\title{
4) 月例講演会
}

第198回 54.7.17. 東京天理教館

「イラン・トルコのキャラバンサライ」(スライド使用)

慶応義塾大学助手 坂本 勉

参会者52名

西アジアには機能からみて二つのタイプのキャラバンサライが存在する。第一は， キャラバンルートに沿って設けられた隊商宿である。第二は，各都市のバーザール， スークに隣接して建てられた卸売商人の事務所として使われるものである。

これまで建築史家はキャラバンサライの現地調査を行なってきたが，その主要な関 心は時代と地域によっ建築様式に差異があることを明らかにすることにあった。この ために中庭, 池,イーワーン, ‘部屋などキャラバンサライを構成する諸要素を精査し， 平面図を作成してきた。

キャラバンサライを歴史学で取りあげる場合, 建築史の成果に立脚しつつその機能 面を抑えていくことが重要である。なかでも，第二のタイプのキャラバンサライがも つ商業機能は，西アジア諸都市の研究をしていく上で大きな意味をもつ。

17世紀のトルコのキャラバンサライについてェウレヤニチェレビの旅行記は, 貴重 な報告を残している。ブルサにあった「アジェムニハン」が，シルヴァーソ，イスフ アハーン，ナフチェバンからやってきたイラン系商人のキャラバンサライであったこ とが述べられている。ブルサは，当時の絹織物業の中心地で，カスピ海南岸のギーラ ーン産の絹をタブリーズ，エルズルム，トカト経由で輸入していた。

一般にキャラバンサライはそれぞれ主要取引商品をもち，商人の構成も同郷的要素 が強かった。19世紀ケルマーンの場合, ヤズド, ファールス, ホラーサーン, キリス 卜教徒出身の各商人が，それ亮れキャラバンサライを構えていたことが知られる。

19世紀イスファハーンの主要なキャラバンサライは, 現在でもバーザールの脇に残 っている。建築構造の平面図と文献史料を対照させていけば，構造と機能を有機的に 復原していくことも可能である。卸売商の事務所としてのホジュレ, 倉庫として保管 機能を果していたサンドゥークンハーネ, 売買機能の場としてのダーラーン（通廊市 場)が重要なものとして挙げることがでさる。

\section{第199回 54.9.25 東京天理教館}

「ヨーロッパにおけるエジプト学の現状」 
第200回 54.10.16. 東京天理教館

「ナバテア人の世界—シルクロードの西端—」

慶応義塾大学教授 小川 英雄 参会者16名 隊商都市の地理的環境が厳しいことは当然であるが，ネゲヴ地方やトランスヨルダ ンのナバテア人の隊商都市はその中でもとりわけ厳しい風土に設立された。その交易 ルートは南アラビアから紅海沿いに約70日でペトラに到り，そこから更に数日かけて ネゲヴ沙漠の隊商都市（アヴダット，ネッッァナ，ハルッッァ，シフタなど）を径て， ガザなどの地中海岸に着くものを幹線路とした。その他に, ペルシア湾方面からアラ ビア沙漠を横断し，ヒジャズ地方を経てペトラに到るルート，ダマスカスからハウラ ン地方を経て南下し, 同じくペトラに着くルートがあった。ナバテア人の商人は前 2 一前 1 世紀に，エジプト，パルティア方面，ェーゲ海域，イタリアに足を延ばした。

最近の考古学的調查の結果, この世界の盛衰が従来よりも具体的に描かれるように なった。(1) a ，ナバテア先王朝時代。前 312 年にペトラ周辺で隊商貿易に従事する遊 牧民としてナバテア人が出るが，その起源は明らかではない。1968年にロンドンに設 立された Arabia Society によるヒジャズ地方の調査研究が, 将来この点を解明して ゆくと期待される。b．ナバテア王朝時代（前169年頃一後106年）。紀元前後のアレ タス 4 世の頃, ナバテア人の社会は定住農耕と都市文明の最盛期に達した。その主要 な担い手は隊商貿易に従事する商業貴族であった。しかし，その後この態勢は著しく 衰光, 最後の王ラベル二世の時代には局地的な灌溉による共同体的農耕生活がネゲヴ 沙漠の諸市で復興した。(2) ローマ帝国への併合後は，3〜4世紀中葉に帝国辺境の 防衛組織の一環として屯田兵が入植し，次第にかつての隊商民ナバテア人は吸収され て行った。(3) ビザンティン時代の 6-7 世紀には再び農耕生活が活発化し，キリス 卜教の教会や修道院を中心とする宗都都市としてかつての隊商都市が復興した。

このよらに，ナバテア人の世界は常に隊商のそれであったのではなく，又都市は常 に隊商貿易を支柱としたのではない。ローマ帝政期の大部分において，これ等の都市 は共同体的農業の中心地であり，キリスト教化以前には大地母神の崇拝が盛んになっ た。

三国時代（220一265年）の魏略, 大秦伝中の積石はペトラ又はその周辺の地方を指 すとされている。この記事の史料となった情報源は必らずしも明らかでないが，これ 
日本オリエント学会だより

を安易にローマとの交易やシルクロード活動を裏付ける史料とし，旧ナバテア領を隊 商世界にとりこむことには用心が必要である。辺境の隊商都市にはかなり急激な盛衰 があり，都市生活が復興してもその原因は隊商貿易以外に求めなくてはならない時期 が意外に多いのである。

第201回 54.12.11. 東京天理教館

「中東と日本一一中山中東ミッションに参加して——」

\section{東京大学助教授 中村廣治郎}

参会者16名

1979年 9 月 8 日より同21日まで，中山賀博中東調査会理事長を団長とする外務省派 遣の「中東との相互理解増進のため調査団」の一員として, エジプト, シリア，イラ ク, サウディ・アラビア, イランの中東五か国を歴訪し, 各界指導者と懇談してきた。 今回は, 先の昭和 51 年 1 月, 53 年 10 月の調査団に次ぐ第三次の調查団である。歴訪の 過程で改めて感じられたことは，まず日本が中東諸国に対して抱く関心と中東諸国が 日本に対して抱く関心の間のギャップ，すなわち石油を中心として政治・経済・文化 そいったトータルな形での日本の中東への関心と, 日本のテクノロジー, 科学, スポ ーツなどの限定された測面に対する中東諸国の日本への関心のギャップである。この ようなギャップの中での相互理解・文化交流の進め方の向題である。これに加えて, 日本と中東諸国の場合, 言葉・宗教の障害の問題がある。このような状沉の中で考え られる具体的な方途の一つは, 先方からも熱望されている柔道・空手を中心とするス ポーツの指導員の派遣と選手の交流である。もらろん，他の分野に特ける人物交流も より一層増進しなければならないことはいらまでもないが，より長期的には，日本の 科学・技術の紹介から, さらには日本の近代化の過程, それを支えた背景, それが生 み出した社会的文化的思想的状沉といったものへと関心を高める具体的努力の積み上 げが必要である。他方，日本にとっては，日本の一方的関心・利害から中東を理解す るのではなく, 対者の現実的諸要請を充分に踏まえた上での中東理解の增進とその具 体的な体制造りが急務である。

5） 新入会員（昭和 54 年 7 月～12月 入会順） (正会員)

近藤 治 追手門学院大学助教授 インド史

干565 大阪府吹田市山田西 3-36-7

内田 杉彦 早稲田大学大学院修士課程 古代エジプト史

干241 横浜市旭区南希望ケ丘84 